\title{
TECHNOLOGICAL PROBLEMS IN MACHINING OF RESILIENT WHEELSETS ON WHEEL-TURNING LATHES WITH FRICTION DRIVE
}

\author{
Krzysztof Filipowicz, Witold Biedunkiewicz, \\ Marcin Królikowski, Dariusz Grzesiak
}

\begin{abstract}
S u m mary
Article presents attempt of identification of technological problems in machining of resilient wheelsets on wheel- turning lathes with friction drive. Main part of presented research was modelling of machined wheel using finite elements method in conditions of load with forces measured during machining of railway wheelsets. Presented research is a part of works performed in order to enable regeneration of tyre profiles of resilient wheelsets using wheel-turning lathes with friction drive, which are commonly used nowadays for machining heavy railway wheelsets.
\end{abstract}

Keywords: Resilient wheels, FEM, turning, technology

Problemy technologiczne w obróbce zestawów kołowych z wkładkami elastycznymi na tokarkach kołowych z napędem ciernym

Streszczenie

W pracy prowadzono analizę wyników próby identyfikacji problemów występujących podczas obróbki zestawów kołowych z wkładkami elastycznymi na tokarkach kołowych z napędem ciernym. Przedstawiono wyniki procesu modelowania obrabianego koła za pomocą metody elementów skończonych w warunkach obciążenia. Wartości siły kreślono podczas obróbki kół kolejowych. Badania są częścią prac prowadzonych w celu ustalenia warunków procesu regeneracji profili jezdnych obręczy zestawów kołowych tramwajowych z wkładkami elastycznymi przy użyciu tokarek kołowych z napędem ciernym. Obrabiarki te są obecnie stosowane do obróbki kół kolejowych.

Słowa kluczowe: zestawy kołowe, MES, toczenie, technologia

\section{Introduction}

Construction of resilient wheels is focused on reduction of vibrations emitted during driving them on rail track so to reduce noise and improve comfort

Address: Prof. Witold BIEDUNKIEWICZ, Krzysztof FILIPOWICZ, M.Sc. Eng., Marcin KRÓLIKOWSKI, Ph.D. Eng., Dariusz GRZESIAK, M.Sc. Eng., West Pomeranian University of Technology, Faculty of Mechanical Engineering and Mechatronics, Institute of Manufacturing Engineering, Al. Piastów 19, 70-310 Szczecin, e-mail: krzysztof.filipowicz@zut.edu.pl, witold.biedunkiewicz@zut.edu.pl, marcin.krolikowski @ zut.edu.pl, dariusz.grzesiak@zut.edu.pl 
of travelling with lightweight railways. That is why resilient wheelsets are commonly used in wagons purposed for city railways. Reduction of vibrations is achieved by inserting elastomer inserts between hard steel wheel tyre, and wheel centre part called hub. This solution is very efficient for vibrations damping while wagon runs, but may cause a problem during machining of such wheelset on wheel-turning lathes, especially that shape of wheel is complicated. The problem is negligible while turning such wheelsets with undertruck lathes. Construction of this lathes simulates conditions of normal work of wheel, on rail track what helps to obtain required shape. Problem in this case is that to renovate wheels all wagon must be delivered to machine tool working space and the same it is out of order for all the renovation cycle of every wheelset. Another problem is that wheels used in one wagon have to have similar diameter, so if one wheelset needs to be regenerated all other in this car must be also turned to fulfil this condition [1-3].

Using wheel-turning lathes enables to regenerate single unmounted wheelset. As one can turn single wheelset it is not necessary to hold the wagon in workshop for all time of regeneration and it is also possible to select wheelsets with similar diameters to be used in particular wagons without necessity of turning all wheels to obtain required dimensions. However classical wheel- turning lathes, weren't able to work with resilient wheelsets due to their construction. For rotating wheels in those lathes are used self-locking dogs that engage inside surface of the wheel tyres. In Resilient wheelsets those surfaces are not available to use without disassembling the wheel. But lately there was invented new kind of wheel turning lathes, that use friction drive to rotate wheelsets during machining. Friction drive is obtained by using driven rollers that are pressed to outside surface of machined tyre with high force. Those machines were made for turning of heavy railway wheels to avoid a risk of destruction of wheel tyre that were turned with classical lathes with self-locking dog. Using a self-locking dogs while machining causes a formation of notches on wheel tyres, what was found to be direct cause of few major accidents of high speed trains in Europe. Friction drive lathes are solving this problem and also don't require an access to inside surface of tyre. So as Friction drive axial lathes started to be efficiently used for regeneration of warn railway tyres, there came the idea of using it also for regeneration of resilient wheelsets [4-6].

One of polish companies that builds friction drive wheel-turning came with proposition to West Pomeranian University of Technology to perform research to see what problems occur during the machining of wheelsets on axial lathes with friction drive and to work out a technology suitable to use this kind of machines for regeneration of resilient wheelsets without disassembling wheels. In order to identify what problem can occur during such machining it was decided to use FEM model to check what kind of deformations occurs in resilient wheel loaded with forces that appear during machining on wheelturning lathes with friction drive [5]. 


\section{Research preparation}

The first aim was to find out the details of construction of resilient wheels. There are few kinds of construction, which differs with shape and way of mounting the elastic inserts. It was decided to create model of most flexible wheels in purpose to get the most adverse conditions for machining. Chosen wheels has dumping inserts made as small pieces of elastomer arranged between hub and tyre of wheel with empty spaces between them (as shown on Fig. 1). This empty spaces also causes a danger of appearing of vibrations during machining by inconstant support of tyre. This construction is also disadvantageous because of large dimensions of elastomer inserts what makes such kind of wheel more flexible than other.

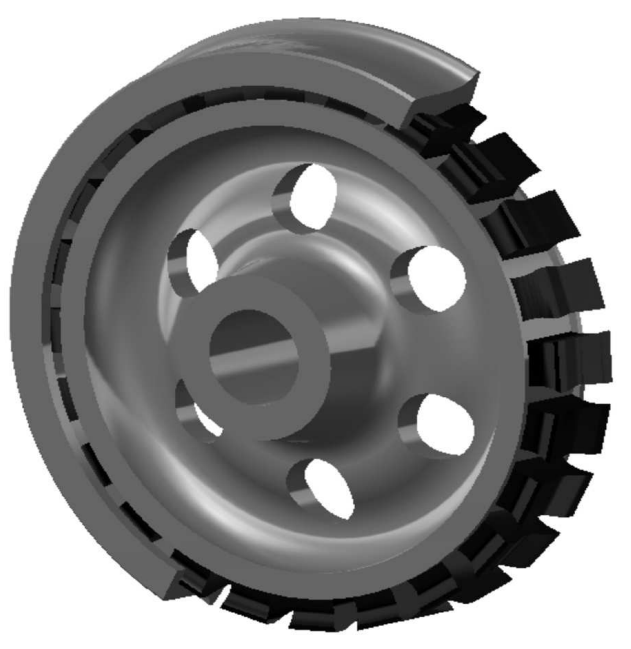

Fig. 1. Pictorial drawing of chosen resilient wheel construction

Next step was gathering information about materials for creating FEM model. Kinds of steel used for manufacturing wheel hubs and tyres is standardized and their properties can be found in the European and Polish standards. But the material used for elastic inserts is not normalized and it's physical and mechanical properties are not wide published. As a matter of fact those properties are known only by the producers of the inserts. Therefore it was necessary to perform tests of the material used for elastic inserts used for resilient wheels to create the FEM model. This tests was performed in material strength laboratory possessed by West Pomeranian University of Technology. For check if the properties of elastic material changes during the usage of inserts 
are changing there was performed series of tests on pieces of material from new and used inserts.

Values of forces acting on the machined wheelsets was also not totally known. Forces of pressing driving rollers to the machined wheels are part of technical data of the wheel-turning lathe with friction drive that was used to perform the research, and they was given by the producer. On the other hand cutting forces are not well known, and they had to be examined. The problem with examination of those forces is that machining of wheelsets is performed with extremely high cutting parameters (area of cut up to $8 \mathrm{~mm}^{2}$ ). This kind of work needs to be performed with special, high power lathes, and using specially designed tools (Fig. 2).

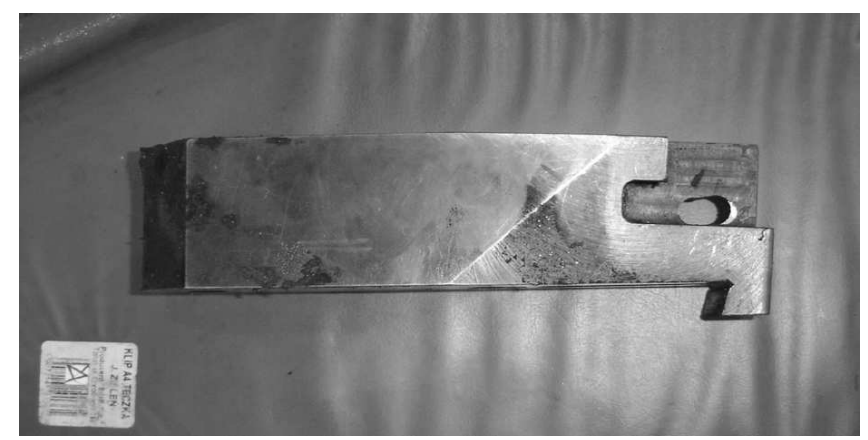

Fig. 2. Standard tool used on wheel-turning lathe

West Pomeranian University of Technology does not possesses enough powerful lathes. Also dimensions of wheelsets are bigger than any of machine owned by University's workshop machine. Therefore it was necessary to perform tests on actually working lathe during machining of railway wheelset. To perform such test it was necessary to build special tool with inserted force meter, that could be used as standard tool for wheel- turning lathes, and such tool was created in workshop of West Pomeranian University of Technology (Fig. 3).

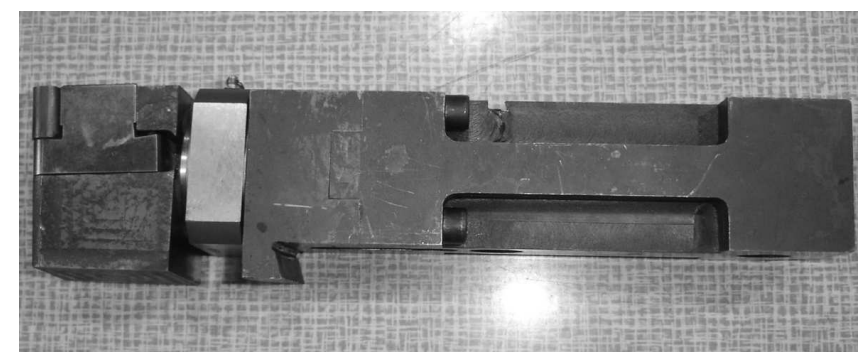

Fig. 3. Special tool with inserted force meter 
After performing a series of tests the values of cutting forces $\left(F_{c}\right)$ were measured and readily implemented into the FEM (Fig. 4).

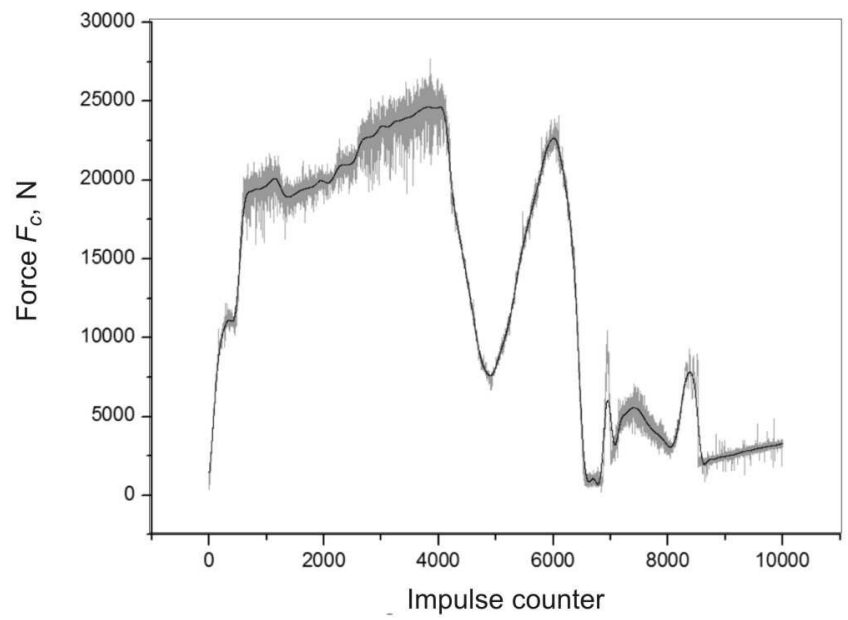

Fig. 4. Cutting force values during the course of machining

\section{Modelling and computations}

For computations was used FEM computer system COSMOSM. In order to obtain possibly as accurate results as possible applied model was made of small solid elements. That also enabled to input forces in distances along the rotation of wheel by angle of 1 degree. This enabled precise positioning of cutting and driving rollers forces. Also it allowed a simulation of rotation of wheel by rotating load forces by 1 degree in each case.

First preliminary computations was made with complete wheel model with assembled hub and axle. Results of those computations shown that displacements on those elements was negligibly small so there was a possibility to remove them from further computations. Instate of it the model was fixed by the inner surfaces of inserts with consideration of displacements of elastic inserts, simulating influence of hub in assembly. It was simplification that made computations less time taking, cause of smaller model.

Actually used model concerned machining of one wheel fastened with revolving centre and driven by 3 rollers pressed to wheel with specified forces and machined with blade sloped with angle 30 degrees from vertical direction what is feature of particular lathe what facilitates removing chips from working space of the machine. Firstly this model was loaded with coplanar force system perpendicular to wheel axis. Driving rollers, and cutting tool was simulated by 
forces and fastening was simulated by displacement in the inner side of elastic inserts (as shown on Fig. 5).
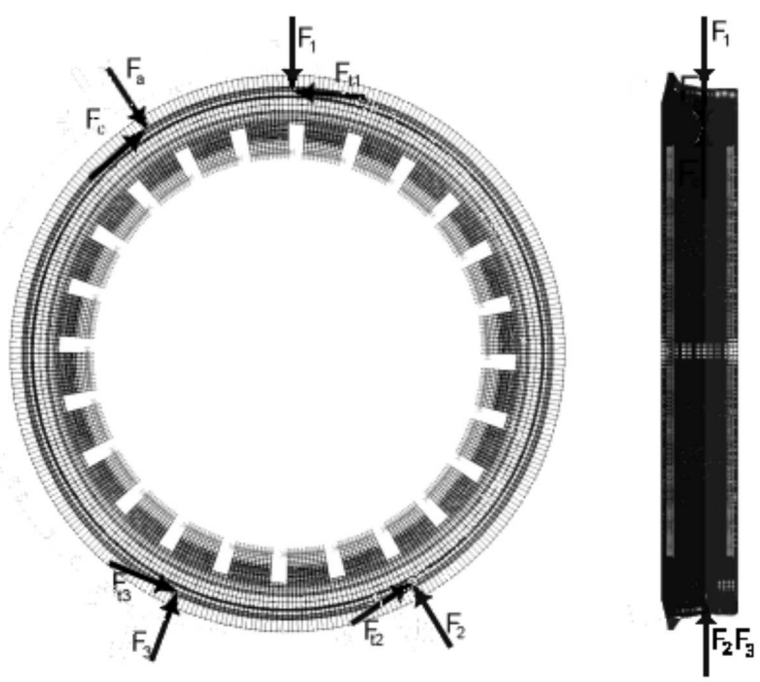

Fig. 5. Static case loads on first FEM wheel model

Forces $F_{1}, F_{2}$ and $F_{3}$ are forces of rollers pressing and their values are:

$$
\begin{gathered}
F_{1}=60000 \mathrm{~N} \\
F_{2}=F_{3}=25000 \mathrm{~N}
\end{gathered}
$$

Forces $F_{a}$ and $F_{c}$ are measured cutting forces and their values are:

$$
F_{a}=F_{c}=25000 \mathrm{~N}
$$

Forces $F_{t 1}, F_{t 2}$ and $F_{t 3}$ are friction forces of the rollers and in this model they applied to counterbalance cutting force $\mathrm{F}_{\mathrm{c}}$

In this model forces was moved along the circumference of wheel to simulate the rotation of wheel during the machining and check the influence of empty spaces between elastic inserts to the radial deformation of tyre measured in point of cutting force load. Every time mutual position of each forces was the same. Checking of the influence of non continue inserts required to perform 15 tests with forces in different positions. In every case the displacements in point of acting of cutting forces was registered (Fig. 6). 


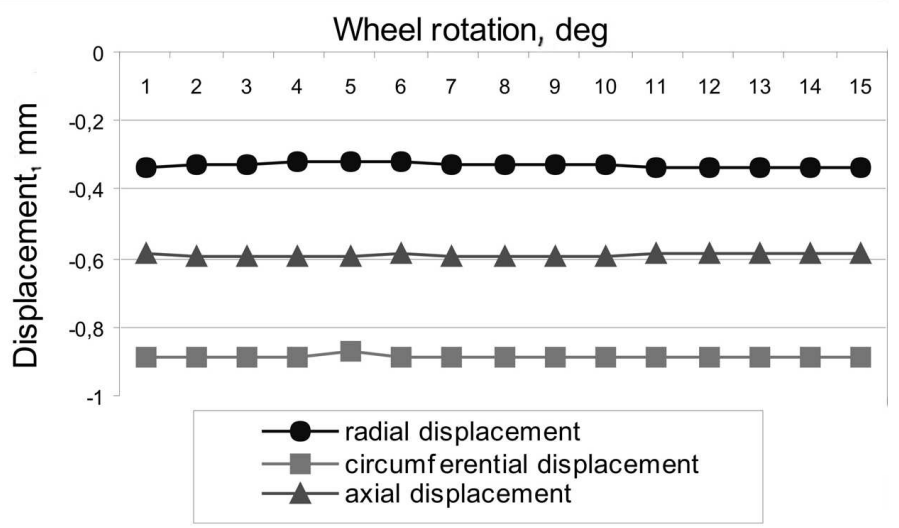

Fig. 6. Registered displacement of point with applied cutting forces in dependence on angular position of machined wheel

As the figure shows the influence of empty spaces between inserts on achieved displacement is negligibly small. So there is no need to taking it into account in computations of further models.

Registered circumferential displacement appeared because main cutting force $\left(F_{c}\right)$ was not perfectly counterbalanced by friction forces. This has no influence on results of research.

Significant is that although there was no force acting any direction except of planar forces, there is a large displacement in direction perpendicular to the plane of wheel (marked with triangles). This direction is parallel to axle of rotation of machined wheel so I call this direction axial.

As the axial displacements was observed in planar model the next step was creating model with applied axial forces (Fig. 7).

Values of forces has not been changed according to coplanar model only the axial (feed) component of cutting force was added:

$$
F_{f}=10000 \mathrm{~N}
$$

The spatial model included also removing of allowance from machined tyre surface. This was achieved by removing rings of elements from outer surface of tyre and placing cutting forces each time in the point uncovered by removed elements. This simulation also enabled to check how wheel tyre would react while material is removed from beneath the rollers. On the diagram of axial displacement it is seen as small refractions in positions 7 and 9. That is why forces of rollers pressing has been divided into three smaller forces in a row and changed while removing elements from places where those forces was applied. This case needed 21 consecutive computations, every one for every removed row of material (elements). 
Sudden change of values of displacement between position 18 and 19 on diagram is caused by machining part of profile from opposite direction what was modelled in accordance to real conditions.

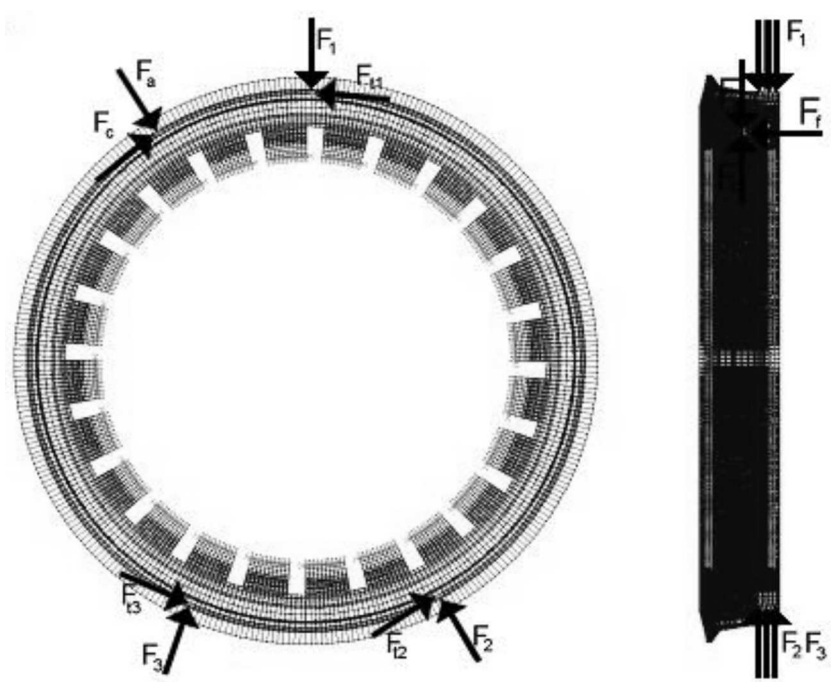

Fig. 7. Static case loads on spatial FEM wheel model

As it has been expected added axial (feed) component of cutting force to model caused high increase of values of axial displacement.

Values of radial displacement did not made any significant change according to coplanar case of loads and still are negligibly small.

\section{Verification}

After performing the FEM computations it became necessary to check if there indeed is such high value of axial displacement. It was not clear if the model was not simplified too much or if there was no any significant error during the computations. Machining was performed on the machined earlier used for measuring the cutting forces, with the same cutting parameters.

As diagram shows, values of displacement are similar that computed using the FEM model. They are not perfectly the same cause of simplification of model, which was static case in opposite to real conditions that are dynamic.

Also there was no observed problem with deformation caused by not continuous inserts. Same as in computations of FEM model. 


\section{Conclusions}

Though FEM model used for computations was not complicated identifications of problems that can occur during machining of resilient wheelsets on wheel- turning lathes with friction drive was reliable.

Although cutting forces are very high, values of radial displacements of machined tyre are negligibly small, and they don't have influence on geometry of machined profile. Also discontinuity of elastic inserts has no significant influence on deformations of machined wheel.

Most problems in machining resilient wheelsets on wheel-turning lathes with friction drive are results of axial displacement of machined wheel during the process. As turning is performed from two different directions such displacements have direct influence on machined profile. Also such a big deformation can cause damage of elastic inserts in resilient wheels.

\section{References}

[1] Poradnik inżyniera - Obróbka skrawaniem. Tom II. WNT, Warszawa 2000.

[2] J. DMOCHOWSKI: Podstawy obróbki skrawaniem. PWN, Warszawa 1983.

[3] E. GÓRSKI: Poradnik frezera. WNT, Warszawa 2000.

[4] W. GRZESIK: Podstawy skrawania materiałów metalowych. WNT, Warszawa 1998.

[5] W. OLSZAK: Obróbka skrawaniem i narzędzia. Wydawnictwo Politechniki Szczecińskiej, Szczecin 2001.

[6] O.C. ZIENKIEWICZ, R.L. TAYLOR, J.Z. ZHU: The Finite element method: its basis and fundamentals. Elsevier Buterrworth-Heinemann, Oxford 2005. 